Article

\title{
A Review on Historical Tsunamis in the Canary Islands: Implications for Tsunami Risk Reduction
}

\author{
Inés Galindo ${ }^{1, *}$, Carmen Romero ${ }^{2}$, Esther Martín-González ${ }^{3}$, Juana Vegas ${ }^{4}\left(\mathbb{D}\right.$ and Nieves Sánchez ${ }^{1}$ (i) \\ 1 Instituto Geológico y Minero de España (IGME, CSIC), Unidad Territorial de Canarias, Alonso Alvarado, \\ 43, 2A, 35003 Las Palmas de Gran Canaria, Spain; n.sanchez@igme.es \\ 2 Departamento de Geografía, Campus de Guajara, Universidad de La Laguna, \\ 38207 La Laguna, Tenerife, Spain; mcromero@ull.edu.es \\ 3 Museo de Ciencias Naturales de Tenerife, Organismo Autónomo de Museos y Centros, Fuente Morales, \\ 1, 38003 Santa Cruz de Tenerife, Tenerife, Spain; mmartin@museosdetenerife.org \\ 4 Instituto Geológico y Minero de España (IGME, CSIC), Ríos Rosas, 23, 28003 Madrid, Spain; j.vegas@igme.es \\ * Correspondence: i.galindo@igme.es
}

check for

updates

Citation: Galindo, I.; Romero, C.; Martín-González, E.; Vegas, J.; Sánchez, N. A Review on Historical Tsunamis in the Canary Islands: Implications for Tsunami Risk Reduction. Geosciences 2021, 11, 222 https://doi.org/10.3390/ geosciences 11050222

\section{Academic Editors}

Jesus Martinez-Frias, Angela Santos and Miguel Llorente Isidro

Received: 31 March 2021

Accepted: 18 May 2021

Published: 20 May 2021

Publisher's Note: MDPI stays neutra with regard to jurisdictional claims in published maps and institutional affiliations.

Copyright: (c) 2021 by the authors. Licensee MDPI, Basel, Switzerland This article is an open access article distributed under the terms and conditions of the Creative Commons Attribution (CC BY) license (https:// creativecommons.org/licenses/by/ $4.0 /)$.

\begin{abstract}
The analysis of the historical documentary sources together with evidence from the geological record is essential to understand the impact and processes triggered by tsunamis on the Canary Islands. This archipelago has been affected by tsunamis caused by different geological processes, of which the most studied have been those generated by prehistoric mega-landslides. However, there is also evidence of those produced by distant tsunamigenic sources. An exhaustive review of all documentation available was made, identifying the existence of at least four seismically triggered tsunami episodes (1755, 1761, 1941 and 1969), the majority with an epicenter in the AzoresGibraltar boundary. In this work, several tsunamis are cited for the first time, such as the one produced by the Argaga (La Gomera) landslide in 2020. Other episodes historically identified as tsunamis are discarded as they corresponded to other geological events. The effects of most historic tsunamis have gone unnoticed, having occurred in epochs of sparsely populated coastal areas. But their study allows us to infer the need for the archipelago authorities to establish preventive measures to avoid possible damage from tsunamis, especially if we consider the presently high population density of the Canarian littoral.
\end{abstract}

Keywords: historical sources; catalogue; tsunami; mitigation; Canary Island; extreme wave event

\section{Introduction}

Tsunamis in the Atlantic are a relatively rare phenomenon compared to other natural events that affect its coastal areas, such as hurricanes, storm surges and floods, although tsunami deposits have been described in several sites in the Atlantic Ocean basin [1]. In the case of oceanic volcanic islands, tsunamis can be generated by submarine volcanic eruptions, pyroclastic flows, gravitational landslides and tsunamigenic earthquakes [2]. Large gravitational landslides occurred in the Canary Islands have generated large tsunami deposits such as the ones that crop out in the Agaete valley, in northwest Gran Canaria [3,4] and in Teno, northwest of Tenerife [5,6]. However, tsunamites produced by other types of events have not been recognized in the geological record, except on La Graciosa Island, where several littoral sedimentary outcrops were reinterpreted [7] as deposits generated during a tsunami produced by an historical earthquake with its epicenter to the SW of the Iberian Peninsula.

In recent decades, an enormous effort has been made in the development of mechanisms and models based on the geological record for predicting tsunamis caused by earthquakes, which have led to the improvement of the models that allow knowing the time of the waves arrival to the coast based on the height of the wave [8]. With this, it has been possible to implement direct and indirect measures to reduce the effects caused by these events. 
Cataloguing and assessing tsunami records from the past is important for long-term tsunami prediction and for tsunami-hazard mapping [9]. Several previous tsunami inventories include events that affected the Canary Islands [10] (and references therein), showing differences between each other. However, historical documents are scarce and they do not allow one to deduce the effects directly derived from tsunamis due to the ignorance of this phenomenon by society in historical times. This is the reason that has prompted the preparation of this work, so that an exhaustive review of the tsunamis that have affected the Canary coasts in historical times is available to determine the affected areas, as well as their source. We also include the description of other tsunami deposits and events not previously reported. With this we have tried to make an approximation to the possible effects of a future tsunami and contribute to the development of preventive management plans.

\section{Materials and Methods}

The research carried out includes the whole Canary Archipelago and is mainly based on documentary records that cover a period of about 500 years, from the conquest of the islands in 1402 to present. Most of the documented tsunamis were preceded by earthquakes felt by the population in the Canary Islands, although some of them correspond to distant earthquakes. All the information collected in previous studies is compiled, incorporating for each event the information related to how the tsunamis affected the Canary coasts. Documentary sources referring to low-frequency episodes, such as tsunamis of a certain intensity, are very difficult to track and assign to a specific event. This fact becomes evident, especially when the information analyzed refers to territories as fragmented as oceanic archipelagos, given their lack of homogeneity and the different types of documentary sources. The disparity has been verified, both in quantity and in reliability of the accounts, depending on the epoch and the social, economic and political-administrative situation for each island. The documentary information used in this work comes from widely scattered sources and appears both in local chronicles, civil and religious reports, regional history books, memoirs, diaries, annals, press and literary texts, and even some manuscripts that remain unpublished from the collection of the 'old library' of the University of La Laguna (https: / / www.ull.es/servicios/biblioteca/\#, (accessed on 21 September 2020).

Efforts have been made, whenever possible, to use primary documentary sources, which are those written contemporaneously with the events that are narrated and which come from a direct source, in most cases and preferably corresponding to direct witnesses of the facts or whose authors are people of recognized historical prestige for their rigor in writing the chronicles. When the data come from secondary sources, that is, from interpretations or analysis of one or more primary sources, it was necessary to go to the primary sources and compare the existing data in both sources. For this study, a tracking and review of documents that were rigorous and productive sources of information in previous studies on historical seismicity and volcanism of the Canary Islands has been carried out [11-15] (among others).

In this work, all the information about tsunamis affecting the Canary coasts has been compiled. All the references in the different historical sources regarding old length units (league, pistol shot) have been transformed to $\mathrm{km}$. It should be clarified that the system of weights and lengths mentioned in many of the sources consulted in this work corresponds to the length measurement systems traditionally used in the Canary Islands. These have varied in time from the Conquest period until the incorporation of the Decimal metric system, already in the 19th century. The equivalences of these length measurements in the Canary archipelago have been established [16], so in this study one league, which is usually established between 4 and $7 \mathrm{~km}$, in the Canary Islands is equivalent to $5572 \mathrm{~m}$. On the other hand, local expressions such as "musket shot" or "pistol shot" were also traditionally used to roughly indicate distances. These distances usually refer not so much to the maximum range of the weapon as to its effective range, that is, the distance that 
allows to hit the target. Thus, the expression "shot from a pistol" is equivalent to a distance of approximately 30 to $50 \mathrm{~m}$.

\section{Geodynamic Setting}

The Canary archipelago is located close to the boundary of the North African and European plates, a transcurrent right lateral fault zone that becomes convergent from the Gorringe bank eastwards $[17,18]$. The convergent segment of the plate boundary is listed as one of the most dangerous from a sismogenic/tsunamigenic point of view, as it was the source of the Lisbon earthquake $M_{\mathrm{w}} 8.5$ on 1 November 1755 [19], as well as other historical events (216-209 BC, 881 AD, 1731 AD), which caused the partial destruction of the coastal cities of the southwestern Iberia and Morocco [20,21]. This zone is still active, as attested by the occurrence of the large earthquakes of 28 February $1969\left(\mathrm{M}_{\mathrm{W}}=7.9\right)$, 26 May $1975\left(\mathrm{M}_{\mathrm{w}}=7.9\right)$ [10], which generated small tsunamis [20,21], and 12 February $2007\left(\mathrm{M}_{\mathrm{w}}=6\right)$ [22], strongly felt in Morocco. These events have also been identified in the sedimentary record in areas as distant as Brazil [23] or the Virgin Islands [24], or others closer such as Azores [25]. For this seismic zone it has been estimated a minimum recurrence period of circa 3600 and 10,000 yr for events of $\mathrm{M}_{\mathrm{w}}=8$ and $\mathrm{M}_{\mathrm{w}}=8.7$ ("1755-like earthquake") respectively, if a single structure (or single combination of structures) is considered [26]. However, if we take into account the major active faults mapped in the region, then estimated recurrence periods are reduced to 700 and $3500 \mathrm{yr}$ or even less, respectively.

In the Canary Islands only a fault located between Gran Canaria and Tenerife Islands (Figure 1), with a NE-SW direction, has been identified [27] as being able to generate big earthquakes. This fault, first inferred from seismic and gravity data by [27], was identified as the source of the 9 May 1989 [27-29], the largest earthquake (mbLg 5.2) recorded in the Canary Islands during the instrumental period. Mantovani et al. [30] proposed the existence of the Morocco microplate whose southern boundary coincides with the location of this left-lateral strike-slip fault. The existence of this major crustal fracture between Tenerife and Gran Canaria based on aeromagnetic inverse modelling is also suggested [31].

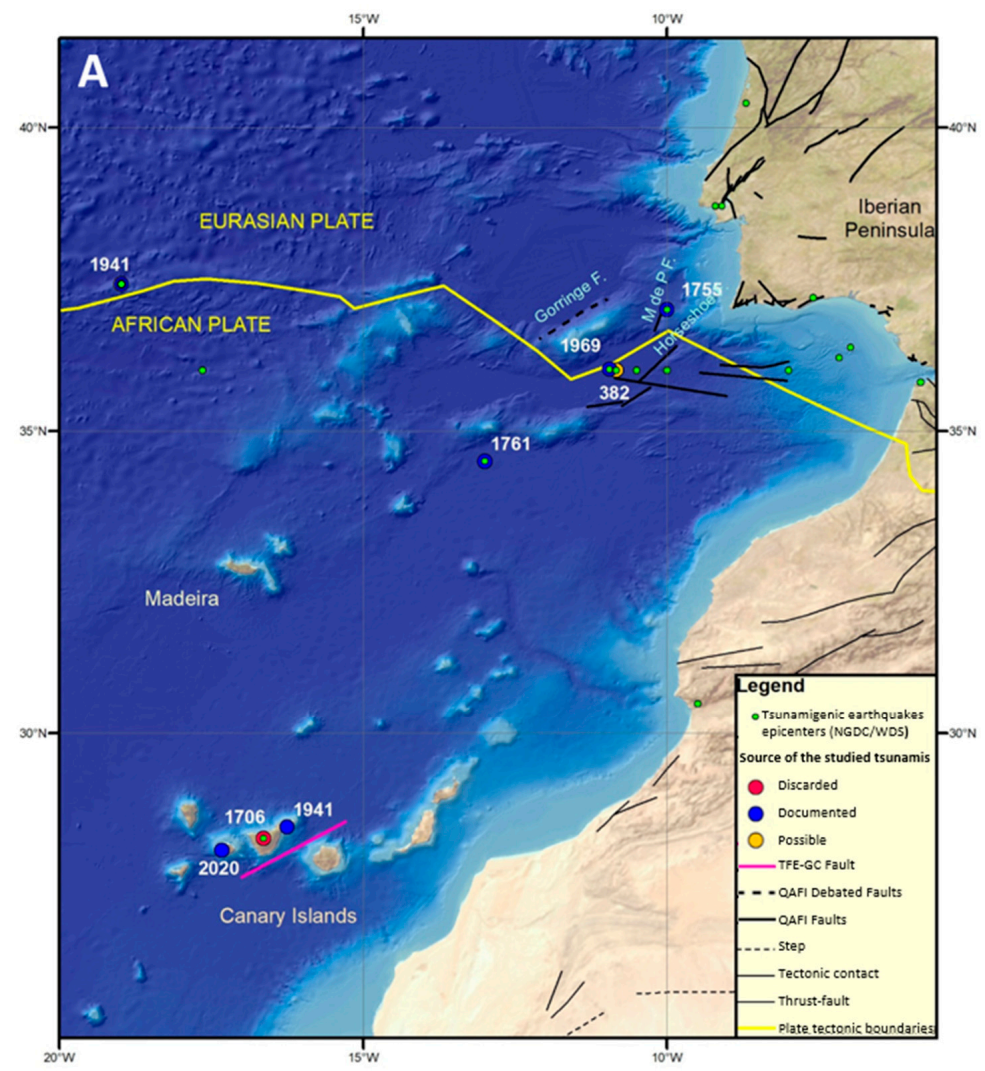

Figure 1. Cont. 


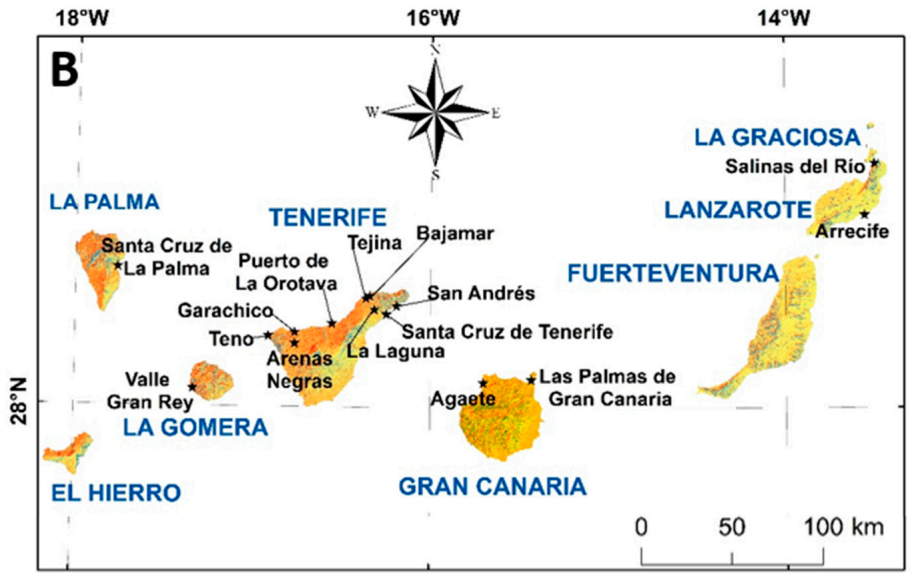

Figure 1. (A) Main tectonic and geodynamic features around the study area showing the Quaternary Faults from the Quaternary Faults Database of Iberia (QAFI) [32] and the tsunamis and earthquakes from the National Geophysical Data Center [33,34], as well as those studied in this work. Faults labelled as rift, step, tectonic contact and thrust-fault retrieved from Global Faults Layer form ArcAtlas (ESRI) [https:/ / services.arcgis.com, (accessed on 8 March 2021)]. Background comes from OAG [https:/ /ags.oag-fundacion.org/arcgis/services, (accessed on 8 March 2021)]. (B) Map of the Canary Islands showing the main localities mentioned in the text.

\section{Documented Tsunamis}

\subsection{The 1 November 1755 Tsunami}

This tsunami was triggered by a $\mathrm{M}_{\mathrm{w}} 8.5$ earthquake (Figure $1 \mathrm{~A}$, Table 1 ) that took place SW of Iberia around 9:30 am [19]. The tsunami devastated the southwest Iberian and north Morocco coasts and was even recorded in North and South America [10,21]. The damage and deaths it caused on the coasts of the Iberian Peninsula were so great that damages occurred in the Canary Islands went almost unnoticed.

Table 1. Synthesis of the tsunami events collected in this article. Reliability scale of the Italian Tsunami Catalogue (Tinti et al.): 0: Very Improbable Tsunami 1: Improbable Tsunami 2: Questionable Tsunami 3: Probable Tsunami 4: Definite Tsunami.

\begin{tabular}{|c|c|c|c|c|c|}
\hline Date & Reference & Geological Source & Location & Mw & Reliability \\
\hline 1 November 1755 & {$[19,35-39]$} & Earthquake & South West Iberia & 8.5 & 4 \\
\hline 31 March 1761 & [37], (de la Guerra y Peña, 1959) & Earthquake & South West Iberia & 8.5 & 4 \\
\hline 7 July 1941 & [Afonso Mosegue, 2001] & Landslide? & Tenerife & - & 3 \\
\hline 25 November 1941 & This work & Earthquake & Gloria Fault & 8.2 & 4 \\
\hline 28 February 1969 & [10] & Earthquake & South West Iberia & 7.9 & 4 \\
\hline 17 July 1969 & [10] & Unknown & South West Iberia & 7.9 & 4 \\
\hline 14 November 2020 & This work & Landslide & La Gomera & - & 4 \\
\hline $382 \mathrm{AD}$ & [7] & Earthquake & South West Iberia & 7.5 & 2 \\
\hline 18 November 1929 & {$[33]$} & Earthquake & Newfoundland & 7.2 & 3 \\
\hline 5 May 1706 & [Silva and Giner-Robles, 2016], this work & Volcanic & Tenerife & - & 0 \\
\hline December 1746 & [39] & Earthquake & Pacific & 8.6 & 0 \\
\hline
\end{tabular}

Around 9:30 a.m. some inhabitants from Tenerife Island felt the earth shaking [35-38], and at the same time, the sea withdrew in Tenerife and Gran Canaria more than $1 \mathrm{~km}$ [35-37,39], later returning inland leaving a flooded distance from the coast of around another $1 \mathrm{~km}[36,38,39]$. Some authors mention that the tsunami affected all the islands [35,37]. The tsunami was described as having affected the whole island of Tenerife, but its impact was stronger along the northern coast $[35,37]$. The inhabitants of Bajamar, Tejina and other localities fled when 
they saw how the sea retreated leaving a large dry strip of at least $1.4 \mathrm{~km}$. At La Orotava the sea came, withdrew a long way and returned with less violence and continued like this with ebb and flow for an hour [36]. In the port of La Orotava a boatman said that his boat had been thrown against the beach, while he was leaning on it with some fishermen and the sea had floated him and had wet them violently up to half a length [36].

In a letter sent from Mr. Ricardo Val to the King Fernando VI, the effects of the 1755 tsunami on the coasts of Gran Canaria, Fuerteventura and Lanzarote are reported [38]. In Gran Canaria, the inhabitants of Las Palmas de Gran Canaria saw from their balconies how the sea retreated for 8 to $10 \mathrm{~min}$, to return with more impulse, repeating the process up to three times. In the port of La Luz the sea flooded the Hermitage of Nuestra Señora de la Luz and when it retired, left it full of fish [40]. After this first flood, the sea retired around 50-90 m, uncovering the hull of an unknown wreck. Some people came to see it, being swept away when the sea returned [36]. In Fuerteventura and Lanzarote the same sea movement was recorded, and on Lanzarote some salt flats that supplied the natives, the Salinas del Río, located at the foot of the Famara cliff, were ruined. The alleged appearance of an image of Saint Juan Bautista floating on the sea in El Hierro Island, after the Lisbon earthquake in 1755, suggests that the tsunami was also felt there [41].

Based on the above, the flood level for the 1755 Lisbon tsunami in the Canary Islands was more than $5 \mathrm{~m}$, which is the height at which the Hermitage of Nuestra Señora de la Luz is located. This height should be taken as a minimum value, since the hermitage was inundated and filled with fishes. Damage caused by the waves was scarce, although it must be considered that the occupation of the coast at that times was very low due to pirate attacks [42].

\subsection{The 31 March 1761 Tsunami}

On 31 March 1761 another transoceanic tsunami was triggered by an 8.5 magnitude earthquake (Figure 1A, Table 1), with epicenter in the southwest of the Iberian Margin $[43,44]$, that was felt in Portugal, Spain and Morocco [10,45]. The tsunami was reported along the south and west coasts of the Iberian Peninsula, the archipelagos of Azores and Madeira, the United Kingdom, and even in Barbados, being affected by waves higher than $1 \mathrm{~m}[10,25,33,43,45,46]$. In previous works there is no mention about the earthquake being felt in the Canary Archipelago. However, it is documented for that day that, around 11:30 a.m., a tremor was felt that lasted around $1 \mathrm{~min}$ and that was felt along the northern coast of Tenerife Island and on La Laguna village [37,47]. The effects on the coast were similar to those reported for the tsunami of 1755 , with the previous withdrawal from the sea and then its rise, which frightened the inhabitants and led them to think on the occurrence of a distant earthquake like the one felt 5 years before [47]. In the same document, this event is related to a strong earthquake that affected the Iberian Peninsula without serious damage, although in Lisbon it was stronger and some buildings collapsed. The results of a recent model of the 1761 tsunami propose wave heights along the northern coast of Tenerife smaller than $0.3 \mathrm{~m}$ and slightly higher to the northeast of the archipelago [44], in accordance with the reported lack of damages in the Canary Islands.

\subsection{The 7 July 1941 Tsunami}

La Tarde newspaper reported three huge waves that, in Tenerife Island, inundated the littoral of Santa Cruz de Tenerife and San Andrés (Figure 1) affecting the Island Council building, the Maritime Avenue, breaking the door of an office and inundating the Navy Command [42]. Only a woman was injured. These waves have been ascribed to a local landslide close to Santa Cruz, since no earthquakes or other extreme wave events occurred that day [42]. Based on this information, the waves surpassed heights of $2 \mathrm{~m}$ in the Cabildo building and $6 \mathrm{~m}$ in the Navy Command. The most likely location of a landslide affecting Santa Cruz would be the $200 \mathrm{~m}$ tall cliffs cut in the old massif to the NE of the city, since the littoral to the SW is mostly low rocky coast. A freak wave is discarded as the origin of this event since they are not characteristic in the eastern coast of the island [42]. 


\subsection{The 25 November 1941 Tsunami}

A Mw 8.3 strike-slip submarine earthquake located offshore Portugal triggered a tsunami that was registered on 25 November 1941 (Figure 1A, Table 1) at tide stations along Portugal, Morocco, Madeira, Azores and UK [10,48,49]. The amplitudes registered in mareograms were $0.25 \mathrm{~m}$ at Casablanca and $0.45 \mathrm{~m}$ at Mogador [50]. In the Canary Islands, tsunami wave observations were reported in the Bulletin of the Seismic Observatory in Almería [51]. The tsunami should had been very low as no news appeared in the On 26 November 1941, some Spanish newspapers reported the earthquake and tsunami in Lisbon $[52,53]$ but did not mention any effect in the Canary Islands confirming the low magnitude and the lack of damages.

\subsection{The 28 February 1969 Tsunami}

A small-amplitude tsunami was generated by a Ms 7.9 earthquake affecting the Atlantic area, with an epicenter located south of the Gorringe Bank [10,25]. The tsunami was recorded by tide gauges in Santa Cruz de Tenerife, Santa Cruz de La Palma, Las Palmas de Gran Canaria and Arrecife in Lanzarote. The local press did not report any sea disturbance for this date.

\subsection{The 17 July 1969 Tsunami}

A small tsunami, of unknown origin, was detected on 17 July 1969 (Table 1) in mareograms of Santa Cruz de Tenerife (Canary Islands), Angra (Terceira Island), Lagos and Cascais (Portugal), being the maximum peak-to-peak amplitude $0.06 \mathrm{~m}$ at Lagos [10,50]. In Casablanca, the tsunami amplitude has been estimated in $0.9 \mathrm{~m}$ [50]. The local press did not echo this event.

\subsection{The 26 May 1975 Tsunami}

The 26 May 1975 tsunami was the result of a Ms 7.9 earthquake located $200 \mathrm{~km}$ south of the Gloria Fault (Figure 1A, Table 1), close to the Tydeman Fracture Zone $[10,54,55]$. The tsunami was observed in Azores archipelago and recorded in tide gauges with a maximum amplitude of $30 \mathrm{~cm}$ at Lagos [10]. In the Canary Islands, this low amplitude tsunami was recorded in a tide gauge located at the Gran Canaria Island main port with a maximum amplitude of $6 \mathrm{~cm}$ [55].

\subsection{The 14 November 2020 Tsunami}

A local tsunami was triggered about 15:00 h on 14 November 2020 in Valle Gran Rey (La Gomera Island) due to a littoral massive rock fall (Figures 1 and 2, Table 1). Videos recording the rock fall posted in the social media allow to observe a tsunami wave propagating radially from the rock fall deposit. The wave, bigger that $0.5 \mathrm{~m}$ near the coast, reached the village of Argaga, more than $200 \mathrm{~m}$ far away, circa $21 \mathrm{~s}$ after the rock fall entering the sea. Sailing tourists reported a small wave that slightly shook the boats anchored less than $400 \mathrm{~m}$ far from the coast. This small tsunami did not cause damages. 


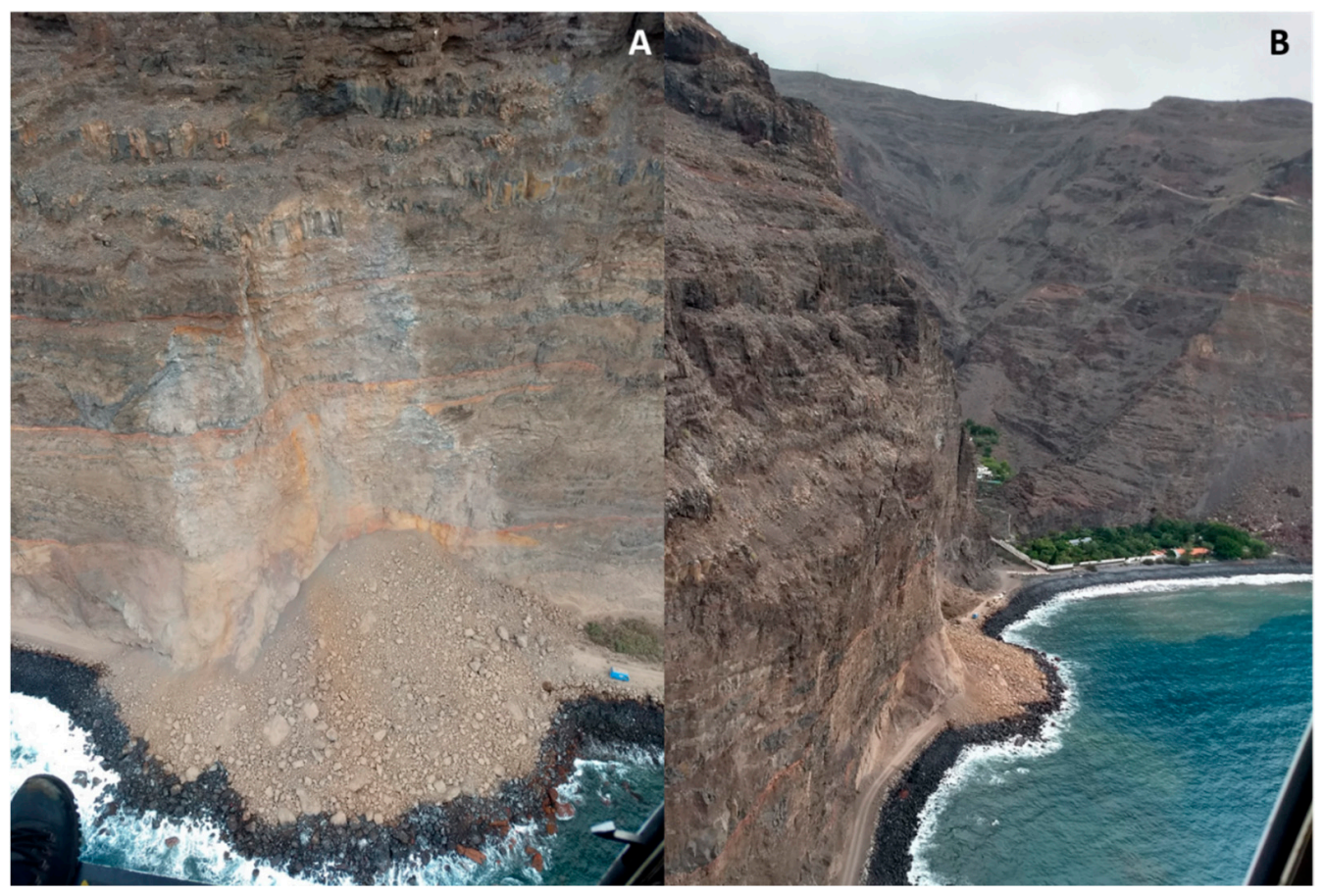

Figure 2. Rock fall of 14 November 2020 in La Gomera Island: (A) Scarp and deposit (see the blue van as scale); and (B) The rock fall deposit and the Argaga beach in the background.

\section{Other Possible Tsunamis}

Several tsunamis have been generated in the tsunamigenic zone of the SW of the Iberian Peninsula [56] (Figure 1, Table 1) but there are no evidences to their impact in the Canary Islands, probably because chronicles for the archipelago did not exist before the $15^{\text {th }}$ century and due to the concentration of the population inland until the end of the $18^{\text {th }}$ century due to pirate incursions. Those tsunamis, triggered by earthquakes with magnitudes higher than $\mathrm{Mw}=7$, could have also affected the Canary Islands. Although there are several other events that may also have considered, we describe below only those tsunamis that are considered of high reliability ("definite tsunamis" in [57]) as well as the $382 \mathrm{AD}$ tsunami that could be at the origin of a tsunami deposit in the Canary Islands [7].

\subsection{A Tsunami in Roman Times?}

Along the eastern coast of La Graciosa Island, both in the intertidal and supratidal area, there is a strongly cemented conglomerate recently described as a tsunamite [7]. It is a polymictic conglomerate (Figure 3 ) that includes boulders and cobbles of the underlying rocks (basalts, beach rocks, marine calcarenites, paleosoil, aeolianites), as well as underwater lithics (reef fragments, well preserved marine shells and bioclasts) and terrestrial fossils. It also contains remains of ceramics and ovicaprid bones of historical age [58] and metal fragments [7]. The deposit dips seawards, from $15^{\circ}$ to sub-horizontal and has an erosional contact with the underlying calcarenites (Figure 3). The deposit is strongly cemented and may be clast-supported, or matrix-supported depending on the outcrop. Incipient reverse grading is reported for the matrix-supported areas and no obvious sorting has been observed in the clast-supported parts of the deposit. The matrix consists of poorly sorted fine to very coarse grained calcarenite with abundant broken and well preserved marine and terrestrial fossil fragments. Lithics are mostly of cobble size, although boulders showing a mayor diameter up to $2.2 \mathrm{~m}$ are also found. Planar boulders and cobbles are imbricated, stacked and dipping seawards. We have carried out a ${ }^{14} \mathrm{C}$ dating experiment on the collagen of a goat tooth obtaining a conventional age of $1730 \pm 30 \mathrm{BP}$, with a $2 \sigma$ calibration (95\% probability) of cal AD 244-cal AD 387. 

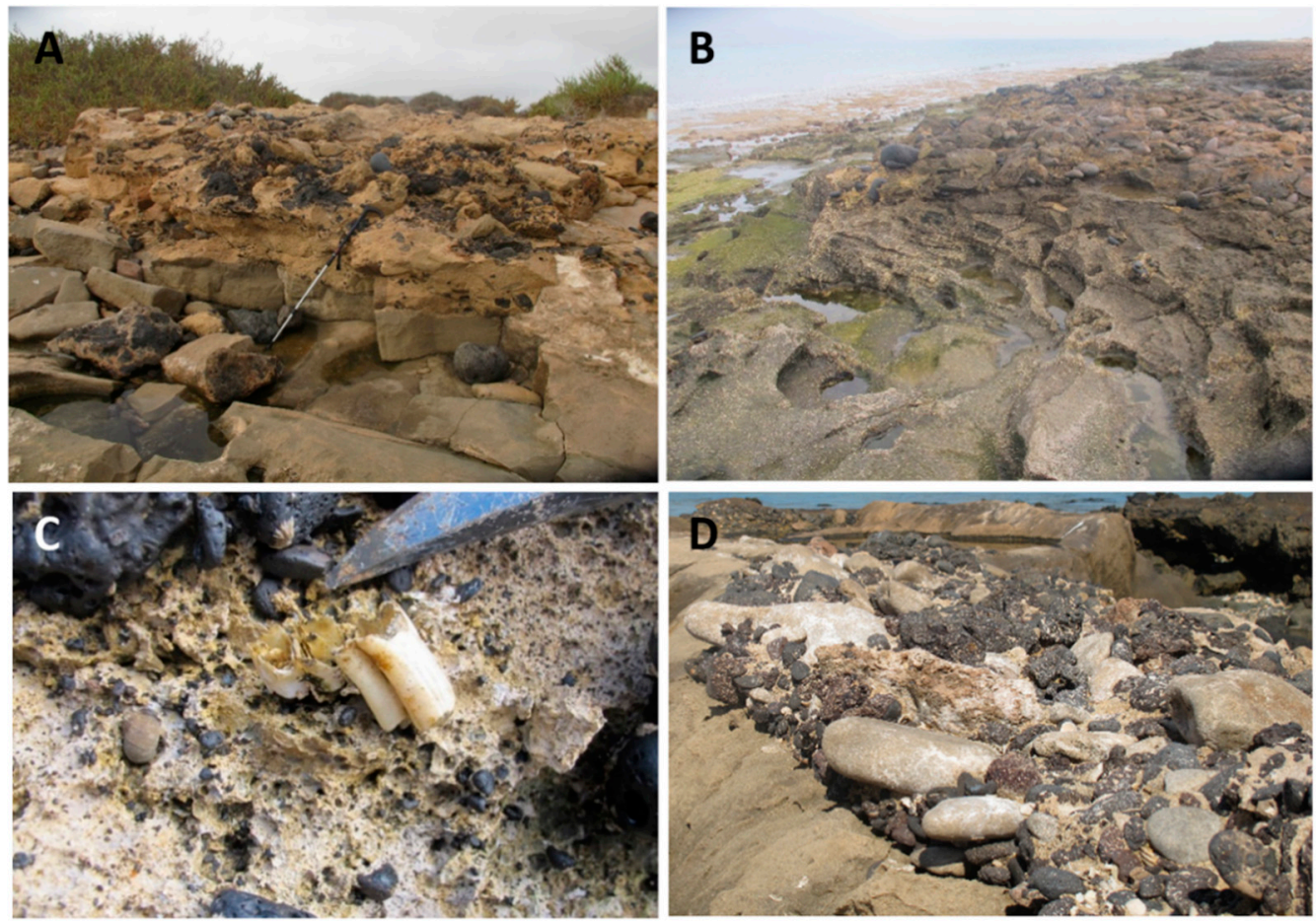

Figure 3. Photographs of La Graciosa $1730 \pm 30$ BP deposit: (A) conglomerate overlying calcarenites (matrix-supported facies); (B) the deposit is dipping seawards; (C) goat tooth found in the deposit; and (D) clast-supported facies of the conglomerate.

It has been postulated that these deposits might have been originated by a tsunami generated by an earthquake with epicenter in the southwest of the Iberian Peninsula, similar to the ones that produced the 1755 and 1761 earthquakes [7]. Sedimentological characteristics fits with an extreme wave event (EWE) deposit. However, it is very difficult to differentiate between a storm and a tsunami EWE deposit $[58,59]$ and a more detail study will be needed. However, exploring the possibilities of being a tsunami, we have checked the historical tsunami records and a tsunamigenic earthquake is in the ranged of age considered for this deposit, the 382 AD. This tsunami was described in Cape St. Vincent (SW Portugal) [60]. The tsunamigenic earthquake had an estimated magnitude of 7.5 [49] and is included in the Portuguese, Moroccan and Mediterranean tsunami catalogues $[10,50,56]$. We do not have documentary evidences of this tsunami since the Canary Islands were conquered in 1402.

This event is also in the range of the age of the earthquake that destroyed the ancient Roman city of Baelo Claudia (Cadiz, Spain), in 260-290 AD [61]. The intensity and magnitude of this earthquake are estimated in IX MSK and 6.3 Ms, respectively [62]. Geoarcheological studies in Baelo Claudia suggest the occurrence of coseismic landslide and tsunami events [63], fact confirmed by the identification of tsunami deposits older than $255 \mathrm{cal}$. AD [64]. However, it has been suggested that the effects of this earthquake were local [65], being related with local faults $20 \mathrm{~km}$ offshore [66].

\subsection{The 18 November 1929 Tsunami}

On 18 November 1929 a Mw 7.2 earthquake with epicenter at the Grand Banks (Newfoundland, Canada) triggered a huge submarine slump and landslide that caused a tsunami that spread across the Atlantic to Antarctica [67,68]. According to the models generated by NOAA's National Geophysical Data Center, the arrival time in the Canary Islands is estimated in around $6 \mathrm{~h}$, similar to Portugal, where the tsunami was recorded. In Portugal, amplitudes observed reached values $<0.2 \mathrm{~m}$ [67], so it probably reached the Canarian coast as a low amplitude tsunami. 


\section{Discarded Tsunamis}

\subsection{The 5 May 1706 Tsunami}

This event is classified as a probable tsunami associated with the 1706 eruption of Arenas Negras in Tenerife Island [33,56,69], which began on May 5 [11]. This assignment is based on the account of Bory de Saint-Vincent [70] who traveled to Tenerife in 1800 and described that "On the night of 5 May 1706, a thunderstorm-like noise was heard underground, and the sea receded. When the lightning day came, the phenomenon which had terrified the unfortunate inhabitants of Garachico, we saw the peak covered with a red and frightful vapor. The air was set ablaze, a smell of sulfur suffocated the terrified animals, which uttered lamentable howls, or plaintive bellows. The waters were covered with a vapor similar to that exhaled from boiling boilers: all of a sudden the earth shakes and opens; torrents of lava, escaping from the crater of Teyde, rush into the plains of the north-west. The city, half engulfed in cracks in the ground, half covered by the vomited lava, disappears entirely. The sea soon returning to its bed, floods the debris of the port which has collapsed; waves and heaps of ashes occupy the place of Garachico, and today we find the remains of the houses, among fragments of lava or in places where ships used to anchor. The inhabitants tried to save themselves by a quick escape, but the majority made useless attempts: some were swallowed up in cracks which, filling in, buried them all alive; others, suffocated by the sulfurous vapors, fell asphyxia in the middle of their chastening race".

The references to the eruption, however, do not mention this tsunami event, nor the catastrophic earthquake [71-73], although these chronicles were made by eyewitnesses or shortly after the eruption. The rest of the references to the eruption, both those made by local figures or historians of proven reliability $[36,41,74]$ or carried out by naturalists of the XIX century are based on these chronicles.

The story of Bory de Saint-Vincent [70] is markedly catastrophic, if compared to Cassares [72]. It is, therefore, a text with a marked romantic style, typical of the moment in which was written [11], and that shows the limitation of his geological knowledge, perhaps also because it is the first contact of the author with a volcanic territory or because he was veiled by the confusion of the time, still tinged by catastrophism, and in the one that Plutonists and Neptunists still fiercely polemicized [75]. In addition, it shows important contradictions-firstly it points out that part of the city's inhabitants were swallowed up by the cracks produced by the earthquakes in Garachico, to finally affirm that there were no human victims-, as well as errors -such as, for example, that the eruption occurred at Teide, when in fact it was related with a fissure-type eruption that was located closer to Garachico. The erroneous location of the eruption at Teide has caused the source of the supposed tsunami to be misidentified in some catalogs [33].

It is possible that Bory de Saint-Vincent mixed the effects of the eruption with those of littoral floods, very frequent in Garachico [14,42,76], many of them with human victims. The information given by this author was collected, in similar terms, in later works [77,78], from where it has passed to the current catalogs of tsumamis. However, based on all the above, we propose to remove this event from the tsunami catalogs.

\subsection{A Tsunami on October 1746}

Álvarez Rixo, author of recognized credibility, was a chronicler and journalist and became mayor of the city of La Orotava between 1828 and 1853. His collection of data on the Canary Islands responds to the author's idea that "all events that are not consigned to the paper are finally forgotten or altered in the traditions". Another document from this author [39] suggests that a tsunami affected the Canary Islands without damages in October 1746: "On a certain day in October, the sea withdrew three times until the Baja Negra, and the people found some things at its bottom. It returned to its site without causing damage and later it was learned of the terrible earthquake and sea growth that destroyed the port of Callao de Lima in Peru. The Roque de Garachico also had to be left dry". 
According to this information, the phenomenon described corresponds to a tsunami that affected the entire north coast of the island of Tenerife, mainly the coast of La Orotava and Garachico, with the withdrawal of the sea and the formation of a train of three waves. The author also mentions the Lima earthquake and tsunami occurred on 28 October 1746. The earthquake struck Perú at 22:30 p.m. destroying the city of Lima and triggering a tsunami that devastated the Callao harbor [79]. This earthquake had an approximate magnitude of $8.6 \mathrm{Mw}$ and the tsunami waves reached highs up to $24 \mathrm{~m}$, taking the lives of 4000 people [80]. This tsunami affected the coasts of Mexico and Buenos Aires [81]. This event has not been reported in the Central Atlantic [10].

The absence of additional information, the lack of coherence between the magnitude of the tsunami and the distance to the epicenter of the earthquake, and the fact that the northern coast of Tenerife, especially the Garachico village, have been affected throughout history by other extreme wave events of climate origin, suggest taking this information with caution in the absence of new evidences.

\section{Discussion and Conclusions}

The short documented historical period in the Canary Islands (from 1402) and the low population density in coastal areas till the second half of the $20^{\text {th }}$ Century, due to its concentration in the interior areas of the islands to defend from the attacks of corsairs, makes it difficult to find evidences of previous tsunamis. Tsunami deposits are also rare due to the presently large human occupation along the coastal areas. In spite of this, at least eight tsunamis are recognized to have affected the Canary Islands coasts (Table 1): two in the $18^{\text {th }}$ century, five in the $20^{\text {th }}$ century and one in the $21^{\text {st }}$ century, plus two other possible events: one in the Roman period and another in the $20^{\text {th }}$ century. These results might allow to update the current catalogues of tsunamis.

Most tsunamis reported here were caused by distant earthquakes with epicenter in the Azores-Gibraltar plate boundary (Table 1), and were small amplitude tsunamis only detected by tide gauges. However, tsunamis like the 1755 , with a minimum run-up distance estimated in $5 \mathrm{~m}$ and an inundation distance of around $1 \mathrm{~km}$ could have major impact in the archipelago. The reported damages for this event were scarce: only some damages in some industrial infrastructures on the northern coast of Lanzarote, such as Las Salinas del Río, and panic scenes among the inhabitants from some coastal towns on the islands of Gran Canaria (Las Palmas de Gran Canaria) and Tenerife (Bajamar and Tejina) (Figure 1B).

Spanish authorities have developed a basic guideline for civil protection planning against tsunami risk to reduce the risk of tsunamis caused by earthquakes [82] based on which different scenarios have been developed, including the Canary Islands area. Maximum wave elevation would be associated with the tsunamis generated in the Gorringe Bank and would mainly affect the northern area of the islands, reaching wave heights of about $8 \mathrm{~m}$ in the El Golfo littoral platform (El Hierro) and in the north of Lanzarote and the Chinijo Archipelago, with arrival times of around $1 \mathrm{~h}$ and the maximum elevation over $2 \mathrm{~h}$. Other scenarios include tsunamis generated in the Caribbean-Puerto Rico zone with arrival times of $7 \mathrm{~h}$. Modelling results suggest maximum wave heights less than $4 \mathrm{~m}$ in Las Palmas de Gran Canaria, where we have estimated minimum run-up value of over $5 \mathrm{~m}$. Future tsunami inundation maps could be developed using numerical models that consider the local reverberation of the waves due to local changes in bathymetry and the proximity of the African coast.

In the case of the tsunamis caused by littoral massive rock falls, like the one occurred on November 2020 in La Gomera Island, the wave spread rapidly to nearby areas, making it more difficult to send alerts and to avoid damages. This one was a relatively small rock fall, but bigger ones can also occur. Waves higher than $6 \mathrm{~m}$ hit Santa Cruz on 7 July 1941, causing some property damages and an injured woman [42]. Thus, littoral rockfalls involving bigger volumes may pose a greater risk, such as that occurred in the Câmara de Lobos in Madeira (1930), which resulted in 19 deaths and 6 injured people [83]. 
Only a tsunami triggered by a megalandslide (a direct consequence of an earthquake) is considered here to have probably affected the archipelago in 1929. However, the occurrence of large landslides in the Canary Islands could be one of the main hazards affecting their coasts. Although they are phenomena of low recurrence, it has been calculated that they can generate tsunamis with large waves reaching more than $100 \mathrm{~m}$ in height ([6] and references therein). For this reason, these catastrophic phenomena pose a risk not only for the Canary Islands but on a global scale, so they should also be considered for future scenarios of tsunamis.

The reported tsunami events corroborate the hypothesis that the Canary Islands, like the eastern Atlantic coasts of the Iberian and Moroccan margin, could be affected in the future by tsunamis triggered by remote earthquakes and by mass movements, in addition to those less frequent but of higher magnitude caused by megalandslides. In order to assess this risk for future scenarios and considering the lack of historical documents before 1492, year of conquest of the Canary Islands, it would be necessary to update tsunami catalogues combining paleotsunamis and historical tsunamis. In addition, it must be considered that the population density in the Canary Islands has increase exponentially since 1755 , as well as the goods exposed. For example, in 1768 the Canary Islands counted with 155,763 inhabitants, while in 2020 the population in the Canary Islands was more than 2.2 million people, with around 292 inhabitants per square $\mathrm{km}$ in 2019, plus a floating population of 300,000 people daily [84]. The presently densely occupied northern part of Las Palmas de Gran Canaria was an unoccupied dune field in 1755 (Figure 4). Furthermore, the population is concentrated in the coastal perimeter of the islands, as well as in the capital cities with two important ports, fundamental for the maritime traffic at a global scale. Territorial planning does not take this hazard into account due to its low recurrence and the lack of information on past events and the low damage caused.

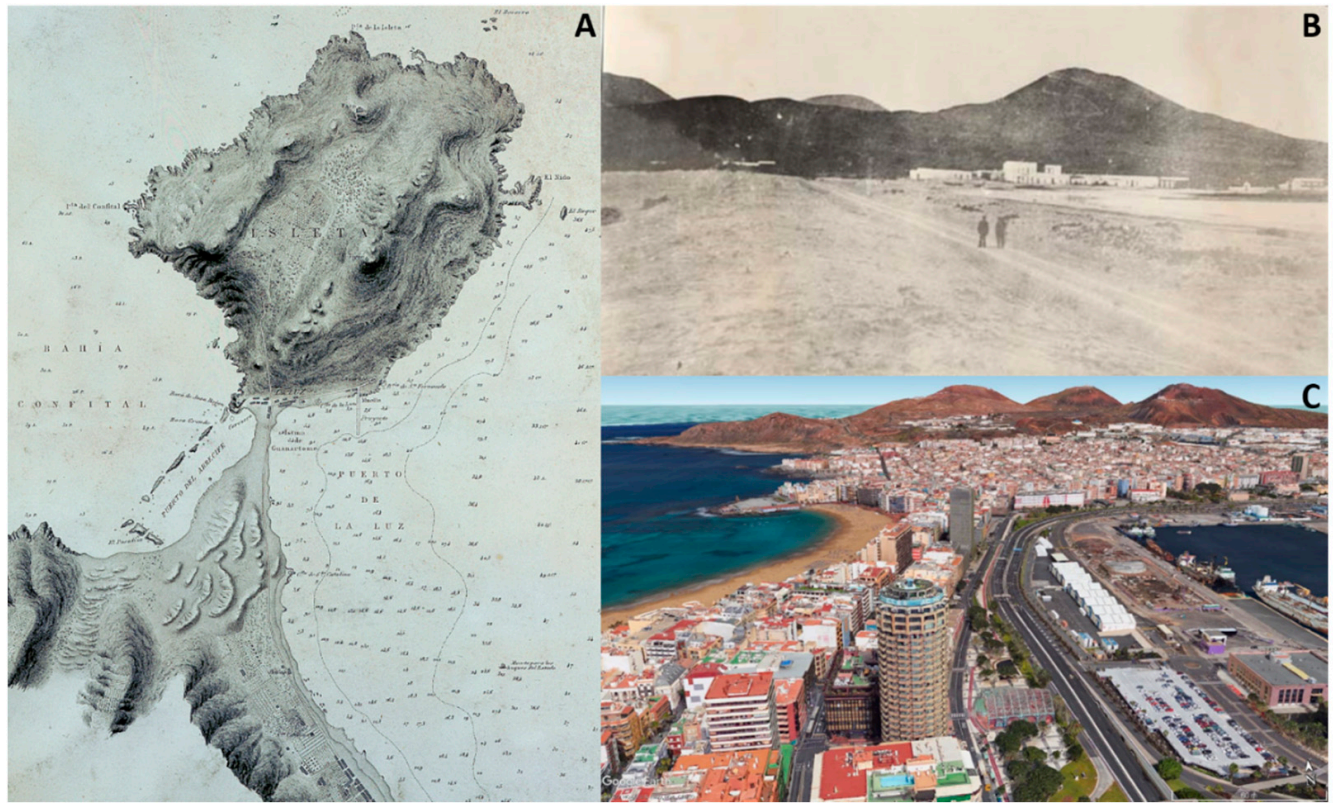

Figure 4. (A) Nautical chart of 1879 of the area of Guanarteme and La Isleta in Gran Canaria Island showing the sandy dune formations along the isthmus (source: https:/ /commons.wikimedia.org/ wiki/File:Isleta-peninsula-Gran-Canaria-Old-Map-1879.jpg, (accessed on 15 March 2021). (B) Photo of the sand fields in the 80s (Source: [Luis Ojeda Pérez]. Archivo de fotografía histórica de Canarias. Cabildo de Gran Canaria. Fedac). (C) Present day view of the northeastern zone of the city where the sand is restricted to the beach (image from Google Earth).

Currently in Europe the tsunami early warning system (NEAMTWS) issues an alert in less than five minutes after an earthquake with tsunamigenic capacity ( $>5.5$ magnitude and with a marine epicenter or near the coast) occurs. It is worth to know that inhabitants 
of the Canary Islands are not aware of the tsunami hazard, neither tourists nor visitors in general, thus there is no knowledge of self-protection measures, such as what to do or where to go during a tsunami. These factors make the vulnerability of the exposed population very high, thus increasing considerably the risk. In the case of far-field tsunamis, arrival times of around $1 \mathrm{~h}$, probably there would not be enough time to evacuate the most densely populated areas without a well-designed and rehearsed evacuation plan, but trained citizens might have enough time to move away from the coast or to elevated areas. In the Canary Islands, the most visited beaches have public address systems, which would facilitate alerts. All this must be accompanied by information and training campaigns for citizens and stakeholders, so that they know the phenomenon, how it can affect them and what they should do if it occurs. Measures should be taken to report the possibility of tsunamis occurrence, to divulge and spread knowledge about the natural phenomena that announce them (e.g., tremors and retreat of the sea) and the preventive actions to be taken in such an event, including emergency scenarios.

It is necessary to adapt the emergency plans of the Autonomous Community of the Canary Islands, whose coasts could be potentially affected by tsunamis, to the Basic Directive of Civil Protection Planning against Seismic Risk [82]. Besides, tsunamis caused by rock falls and megalandslides should also be considered into emergency plans in the Canary Islands, including an effective warning system and an education program focused on all stakeholders and also on local residents, visitors and students. It is also crucial to study littoral deposits in the Canary Islands to improve our knowledge about tsunamis and other extreme wave events, since they could have more destructive effects due to the increase in sea level and the frequency of extreme storms due to climate change.

Author Contributions: Conceptualization, I.G., C.R., E.M.-G., J.V. and N.S.; Funding acquisition, I.G.; Investigation, I.G., C.R., E.M.-G., J.V. and N.S.; Project administration, I.G.; Supervision, I.G.; Visualization, I.G., E.M.-G. and N.S.; Writing—original draft, I.G., C.R. and E.M.-G.; Writing-review \& editing, I.G., C.R., E.M.-G., J.V. and N.S. All authors have read and agreed to the published version of the manuscript.

Funding: Field work was carried out in the framework of LIGCANARIAS project (ProID2017010159) funded by the Canarian Agency for Research, Innovation, and Society of Information (ACIISI) under the Government of the Canary Islands.

Institutional Review Board Statement: Not applicable.

Informed Consent Statement: Not applicable.

Acknowledgments: This work was carried out with support from the agreement between IGME and CCS (BOE-A-2019-6473) and the Associated Unit INGEA (BOE-A-2020-13191). The authors also thank the collaboration in fieldwork in La Graciosa to Cabildo de Lanzarote, the UNESCO Global Geopark of Lanzarote and Chinijo Islands and the Finca Patrimonial de La Graciosa. D. Luis Regueira, responsible for the Library of the Canarian Museum (Las Palmas de Gran Canaria) helped in consulting some documents from the newspaper library. The authors are also grateful to the four anonymous reviewers, whose comments have greatly enriched this article.

Conflicts of Interest: The authors declare no conflict of interest.

\section{References}

1. Costa, P.; Dawson, S.; Ramahlo, R.; Engel, M.; Dourado, F.; Bosnic, I.; Andrade, C. A review on onshore tsunami deposits along the Atlantic coast. Earth-Sci. Rev. 2020, 212, 11-19. [CrossRef]

2. Paris, R. Source mechanisms of volcanic tsunamis. Phil. Trans. R. Soc. A 2015, 373, 20140380. [CrossRef] [PubMed]

3. Perez-Torrado, F.J.; Paris, R.; Cabrera, M.C.; Schneider, J.L.; Wassmer, P.; Carracedo, J.C.; Rodriguez Santana, A.; Santana, F. The Agaete tsunami deposits (Gran Canaria): Evidence of tsunamis related to flank collapses in the Canary Islands. Mar. Geol. 2006, 227, 137-149. [CrossRef]

4. Madeira, J.; Ferrer Gijón, M.; Gonzalez de Vallejo, L.I.; Andrade, C.; Freitas, M.; Lomoschitz, A.; Hoffman, D.L. Agaete revisited: New data on the Gran Canaria tsunamiites. Geophys. Res. Abstr. 2011, 13, EGU2011-EGU2292.

5. Paris, R.; Coello Bravo, J.J.; Martín González, M.E.; Kelfoun, K.; Nauret, F. Explosive eruption, flank collapse and mega-tsunami at Tenerife ca. 170 ky ago. Nat. Commun. 2017, 8, 15246. [CrossRef] [PubMed] 
6. Paris, R.; Ramalho, R.S.; Madeira, J.; Ávila, S.; May, S.M.; Rixhon, G.; Engel, M.; Brückner, H.; Herzog, M.; Schukraft, G.; et al. Mega-tsunami conglomerates and flank collapses of ocean island volcanoes. Mar. Geol. 2018, 395, 168-187. [CrossRef]

7. Galindo, I.; Romero, M.C.; Martín-González, E.; Vegas, J.; Sánchez, N. A tsunamite in the Canary Islands caused by a distant earthquake. In Abstract Volume of the 5th International Tsunami Field Symposium; Costa, P.J.M., Andrade, C., Freitas, M.d.C., Eds.; Universidade de Lisboa: Lisboa, Portugal, 2017; p. 44.

8. Gibbons, S.J.; Lorito, S.; Macías, J.; Løvholt, F.; Selva, J.; Volpe, M.; Sánchez-Linares, C.; Babeyko, A.; Brizuela, B.; Cirella, A.; et al. Probabilistic Tsunami Hazard Analysis: High Performance Computing for Massive Scale Inundation Simulations. Front. Earth Sci. 2020, 8, 591549. [CrossRef]

9. Arcos, N.P.; Dunbar, P.K.; Stroker, K.J.; Kong, L.S.L. The impact of post-tsunami surveys on the NCEI/WDS global historical tsunami database. Pure Appl. Geophys. 2019, 176, 2809-2829. [CrossRef]

10. Baptista, M.A.; Miranda, J.M. Revision of the Portuguese catalog of tsunamis. Nat. Hazards Earth Syst. Sci. 2009, 9, 25-42. [CrossRef]

11. Romero, C. Las Manifestaciones Volcánicas del Archipiélago Canario; Consejería de Política Territorial del Gobierno Autónomo de Canarias: Santa Cruz de Tenerife, Tenerife, Spain, 1991; Volume 2, p. 1463.

12. Romero, C. Estudio Geomorfológico de los Volcanes Históricos de Tenerife; Aula de Cultura del Cabildo de Tenerife: Santa Cruz de Tenerife, Tenerife, Spain, 1992; p. 265.

13. Romero, C. Crónicas Documentales Sobre las Erupciones de Lanzarote: Erupción de Timanfaya (1730-1736), Erupción del Volcán de Tao, Nuevo del Fuego y Tinguatón (1824); Fundación César Manrique: Madrid, Spain, 1997; p. 167.

14. Romero, C.; Beltrán, E. La Erupción de Arenas Negras, Garachico, 1706. Evolución de un paisaje volcánico; Viceconsejería de Medio Ambiente del Gobierno de Canarias: Santa Cruz de Tenerife, Tenerife, Spain, 2007; p. 257.

15. Romero, C.; Beltrán, E. El impacto de las coladas de 1706 en la ciudad de Garachico. (Tenerife, Islas Canarias, España). Investig. Geográficas 2015, 63, 99-115. [CrossRef]

16. De la Coba García, D. Pesas y medidas utilizadas en Canarias. Rev. Didáctica Matemáticas 1982, 2, 9-22.

17. Buforn, E.; Bezzeghoud, M.; Udías, A.; Pro, C. Seismic sources on the Iberia-African plate boundary and their tectonic implications. Pure Appl. Geophys. 2004, 161, 623-646. [CrossRef]

18. Stich, D.; Mancilla, F.; Morales, J. Crust-mantle coupling in the Gulf of Cadiz (SW Iberia). Geophys. Res. Lett. 2005, 32, L13306. [CrossRef]

19. Martínez Solares, J.M.; Arroyo, A. The great historical 1755 earthquake. Effects and damage in Spain. J. Seism. 2004, 8, 275-294. [CrossRef]

20. El Mrabet, T. Les grands seismes dans la region maghrebine. State Thesis, Faculte des Lettres et des Sciences Humaines, Universite Mohammed, V., Rabat, Morocco, 2005; p. 435.

21. Lario, J.; Zazo, C.; Goy, J.L.; Silva, P.G.; Bardaji, T.; Cabero, A.; Dabrio, C.J. Holocene palaeotsunami catalogue of SW Iberia. Quat. Int. 2011, 242, 196-200. [CrossRef]

22. Stich, D.; Mancilla, F.; Pondrelli, S.; Morales, J. Source analysis of the February 12th 2007, Mw 6.0 Horseshoe earthquake: Implications for the 1755 Lisbon earthquake. Geophys. Res. Lett. 2007, 34, L12308. [CrossRef]

23. Dourado, F.; Costa, P.; Omira, R.; Cezario, A.P.; Beltrão, B.; Elldorf, B.; Días, G. Transantlantic tsunami records in Brazil. In Abstract Volume of the 5th International Tsunami Field Symposium; Costa, P.J.M., Andrade, C., Freitas, M.d.C., Eds.; Universidade de Lisboa: Lisboa, Portugal, 2017; p. 52.

24. Atwater, B.F.; ten Brink, U.S.; Cescon, A.L.; Feuillet, N.; Fuentes, Z.; Halley, R.B.; Nuñez, C.; Reinhardt, E.G.; Roger, J.H.; Sawai, Y.; et al. Extreme waves in the British Virgin Islands during the last centuries before 1500 CE. Geosphere 2017, 13, 301-368. [CrossRef]

25. Andrade, C.; Borges, P.; Freitas, M.C. Historical tsunami in the Azores archipelago (Portugal). J. Volcanol. Geotherm. Res. 2006, 156, 172-185. [CrossRef]

26. Matias, L.M.; Cunha, T.; Annunziato, A.; Baptista, M.A.; Carrilho, F. Tsunamigenic earthquakes in the Gulf of Cadiz: Fault model and recurrence. Nat. Hazards Earth Syst. Sci. 2013, 13, 1-13. [CrossRef]

27. Mezcua, J.; Buforn, E.; Udías, A.; Rueda, J. Seismotectonics of the Canary Islands. Tectonophysics 1992, 208, 447-452. [CrossRef]

28. Jiménez, M.J.; García-Fernández, M. Aftershock sequence of the 9 May 1989 Canary Islands earthquake. Tectonophysics 1996, 255, 157-162. [CrossRef]

29. Bosshard, E.; Macfarlane, D. Crustal structure of the western Canary Islands from seismic refraction and gravity data. J. Geophys. Res. 1970, 75, 4901-4918. [CrossRef]

30. Mantovani, E.; Viti, M.; Babucci, D.; Albarello, D. Nubia-Eurasia kinematics: An alternative interpretation from Mediterranean and North Atlantic evidence. Ann. Geophys. 2007, 50, 341-366.

31. Blanco-Montenegro, I.; Montesinos, F.G.; Arnoso, J. Aeromagnetic anomalies reveal the link between magmatism and tectonics during the early formation of the Canary Islands. Sci. Rep. 2018, 8, 42. [CrossRef] [PubMed]

32. Instituto Geológico y Minero de España (IGME). QAFI v.3: Quaternary Faults Database of Iberia. Available online: http: / / info.igme.es/QAFI (accessed on 8 March 2021).

33. National Geophysical Data Center/World Data Service (NGDC/WDS): NCEI/WDS Global Significant Earthquake Database; NOAA National Centers for Environmental Information. Available online: https:/ /www.ngdc.noaa.gov/hazel/view/hazards/ earthquake/search (accessed on 4 March 2021). [CrossRef] 
34. National Geophysical Data Center/World Data Service: NCEI/WDS Global Historical Tsunami Database, 2100 BC to Present. Available online: https:/ / www.ngdc.noaa.gov/hazard/tsu_db.shtml (accessed on 2 February 2021).

35. Anchieta, J.A. de Diario. (Apuntes curiosos) 1747-1764; Manuscrito: Biblioteca Universidad de La Laguna; Volume II, sig. 83-2-20, fol. 175v-176. Available online: https://hermes.bbtk.ull.es/pandora/cgi-bin/Pandora.exe?fn=select;collection=manuscritos paginas;field=alt_record_id;query=BAB20090863613;sort=\%2Bsource+\%2Bpage; $x$ slt=issue;lang=es;length=1;title=Diario $\% 20$ \%5BManuscrito\%5D\%20:\%20(apuntes\%20curiosos (accessed on 15 January 2021).

36. Glas, G. Descripción de las Islas Canarias; Instituto de Estudios Canarios: La Laguna, Tenerife, Spain, 1764; pp. 98-99.

37. Anchieta y Alarcón, J. Diario. José de Anchieta y Alarcón, 1st ed.; García Pulido, D., Ed.; Ediciones Idea: Santa Cruz de Tenerife, Tenerife, Spain, 2011; Volume 2.

38. De León Hernández, J. Efectos del terremoto de Lisboa de 1755 en Canarias. In Canarias insólita. Bestias, Fenómenos y Calamidades; Manuel de Paz, Ed. Herques: Tenerife, Spain, 2017; pp. 127-132.

39. Álvarez Rixo, J.A. Anales del Puerto de la Cruz y de La Orotava, 1701-1872; Cabildo Insular de Tenerife y Patronato de Cultura del Ayuntamiento del Puerto de la Cruz: Puerto de la Cruz, Santa Cruz de Tenerife, Spain, 1994; p. 62.

40. Anaya Hernández, L.A. Un tsunami en Canarias. Canarii 2007, 7, 16-17.

41. Viera y Clavijo, J. Noticias de la Historia General de las Islas Canarias, 1776; Goya Ediciones: Santa Cruz de Tenerife, Tenerife, Spain, 1950; p. 471.

42. Afonso Mosegue, J. Canarias y los eventos extremos en el mar. Bol. RSEAP 2011, 1, 63-112.

43. Baptista, M.A.; Miranda, J.; Luis, J. In Search of the 31 March 1761 Earthquake and Tsunami Source. Bull. Seism. Soc. Am. 2006, 96, 713-724. [CrossRef]

44. Wronna, M.; Baptista, M.A.; Miranda, J.M. Reanalysis of the 1761 transatlantic tsunami. Natural Hazards and Earth Sys. Sci. 2019, 19, 337-352. [CrossRef]

45. Borlase, W. Some Account of the extraordinary Agitation of the Waters in Mount's-bay, and other Places, on the 31st of March 1761, In: A Letter for the Reverend Dr. C Lyttelton. Philos. T. Roy. Soc. 1762, 52, 418-431.

46. Cantavella Nadal, J.V. La sorprendente fuerza del agua: Los tsunamis. Anuario del Observatorio Astronómico de Madrid 2015, 1, 409-436.

47. de la Guerra y Peña, L.A. Memorias (Tenerife en la Segunda Mitad del Siglo XVIII). Cuaderno I (Años 1760-70); El Museo Canario: Las Palmas de Gran Canaria, Las Palmas, Spain, 1959; p. 156.

48. Udías, A.; López Arroyo, A.; Mezcua, J. Seismotectonic of the Azores-Alboran Region. Tectonophysics 1976, 31, 259-289. [CrossRef]

49. Martins, I.; Victor, L.A.M. Contribution to the Study of Seismicity in the West Margin of Iberia. Univ. Lisboa. IGIDL Pub 2001, 25. 0870-2748.

50. Kaabouben, F.; Baptista, M.A.; Ibem Brahim, A.; El Mouraouah, A.; Toto, A. On the Moroccan tsunami catalogue. Nat. Hazards Earth Syst. Sci. 2009, 9, 1227-1236. [CrossRef]

51. Baptista, M.A.; Miranda, J.M.; Batlló, J.; Lisboa, F.; Luis, J.; Maciá, R. New study on the 1941 Gloria Fault earthquake and tsunami. Nat. Hazards Earth Syst. Sci. Discuss 2016, 16, 1967-1977.

52. La Tarde Newspaper. 26 July 1941. Available online: http:/ / www.elmuseocanario.com/listado-periodicos-cronologico/?catp=17 (accessed on 3 May 2021).

53. Falange Newspaper. 27 July 1941. Available online: http://www.elmuseocanario.com/listado-periodicos-cronologico/?catp=17 (accessed on 3 May 2021).

54. Lynnes, C.S.; Ruff, L.J. Source process and tectonic implications of the 1975 North Atlantic earthquake. Geophys. J. Royal Astron. Soc. 1985, 82, 497-510. [CrossRef]

55. Kaabouben, F.; Brahim, A.J.; Toto, E.; Baptista, M.A.; Miranda, J.M.; Soares, P.; Luis, J.F. On the focal mechanism of the 26.05 .1975 North Atlantic event contribution from tsunami modeling. J. Seismol. 2008, 12, 575-583. [CrossRef]

56. Maramai, A.; Graziani, L.; Brizuela, B. Euro-Mediterranean Tsunami Catalogue (EMTC), version 2.0. Ann. Geophys. 2019. [CrossRef]

57. González-Antón, R.; del Arco, M.C. Navegaciones exploratorias en Canarias a finales del II Milenio a.c. e inicios del primero. El cordón litoral de La Graciosa (Lanzarote). Canarias Arqueol. 2009, 17, 9-79.

58. Lario Gómez, J.; Luque Ripoll, L.D.; Zazo Cardeña, C.; Goy Goy, J.L.; Spencer, C.; Cabero del Río, A.; Alonso Azcárate, J. Tsunami vs. storm surge deposits: A review of the sedimentological and geomorphological records of extreme wave events (EWE) during the Holocene in the Gulf of Cadiz, Spain. Z. Geomorphol. Suppl. 2010, 54 (Suppl. 3), 301-316. [CrossRef]

59. Sakuna-Schwartz, D.; Feldens, P.; Schwarzer, K.; Khokiattiwong, S.; Stattegger, K. Internal structure of event layers preserved on the Andaman Sea continental shelf, Thailand: Tsunami vs. storm and flash-flood deposits. Nat. Hazards Earth Sys. Sci. 2015, 15, 1181-1199. [CrossRef]

60. Brito, F.B. Monarquia Lusitana, Lisboa Imprensa Nacional; Casa da Moeda, Facsimile: Lisbon, Portugal, 1973-1988; 877p.

61. Silva, P.G.; Reicherter, K.; Grützner, C.; Bardají, T.; Lario, J.; Goy, J.L.; Becker-Heidmann, P. Surface and subsurface palaeoseismic records at the ancient Roman city of Baelo Claudia and the Bolonia Bay area, Cádiz (south Spain). Geol. Soc. London Spec. Public. 2009, 316, 1-4, 129-146. [CrossRef]

62. Espinar Moreno, M. Los estudios de sismicidad histórica en Andalucía: Los terremotos históricos de la provincia de Almería. In El estudio de los terremotos en Almería; Posadas, A.M., Coord.; Instituto de Estudios Almerienses: Almería, Spain, 1994; pp. 115-180. 
63. Silva, P.G.; Giner-Robles, J.L. Ancient earthquakes in the Roman city of Baelo Claudia (Cádiz, South of Spain): Fifteen years of archaeosimology research [Los terremotos antiguos del conjunto arqueológico romano de Baelo Claudia (Cádiz, Sur de España): Quince años de investigación arqueosismológica]. Est. Geol. 2016, 72, e050.

64. Röth, J.; Mathes-Schmidt, M.; García Jiménez, I.; Rojas Pichardo, F.J.; Grützner, C.; Silva, P.G.; Reicherter, K. The Baelo Claudia tsunami hypothesis: Results from a multi-method sediment analysis of late-Roman deposits (Gibraltar Strait, Southern Spain). In Proceedings of the 6th International Inqua Meeting on Paleoseismology, Active Tectonics and Archaeoseismology, Pescina, Fucino Basin, Italy, 19-24 April 2015; pp. 19-24.

65. Silva, P.G.; Borja, F.; Zazo, C.; Goy, J.L.; Bardají, T.; De Luque, L.; Lario, J.; Dabrio, C.J. Archaeoseismic record at the ancient Roman City of Baelo Claudia (Cádiz, south Spain). Tectonophysics 2005, 408, 1-4. [CrossRef]

66. Grützner, C.; Reicherter, K.; Hübscher, C.; Silva, P.G. Active faulting and neotectonics in the Baelo Claudia area, Campo de Gibraltar (southern Spain). Tectonophysics 2012, 554, 127-142. [CrossRef]

67. Fine, I.V.; Rabinovich, A.B.; Bornhold, B.D.; Thomson, R.E.; Kulikov, E.A. The Grand Banks landslide generated tsunami of November 18, 1929: Preliminary analysis and numerical modelling. Mar. Geol. 2005, 215, 45-57. [CrossRef]

68. Løvholt, F.; Schulten, I.; Mosher, D.; Harbitz, C.; Krastel, S. Modelling the 1929 Grand Banks slump and landslide tsunami. Geol. Soc. Lond. Spec. Publ. 2018, 477, 315-331. [CrossRef]

69. Instituto Geográfico Nacional. 2021. Available online: https://www.ign.es/web/resources/docs/IGNCnig/SIS-CatalogoTsunamis-Costas-Espanolas.pdf (accessed on 21 December 2020).

70. Bory de Saint-Vincent, J.B.G.M. Essais sur Les Isles Fortunées et l'Antique Atlantide ou Précis de l'Histoire générale de l'Archipel des Canaries; Baudouin: Paris, France, 1903; p. 542.

71. García, F.J. Papeles referentes al Convento franciscano de Nuestra Señora de los Ángeles, de Garachico, Tenerife [1701-1769]. Archivo Histórico Nacional. [Manuscrito] MSS_008957, 1707. Available online: http:/ /bdh-rd.bne.es/viewer.vm?id=0000139682 \&page $=1$ (accessed on 14 January 2021).

72. Cassares, D.J. Breve narrativa de la lamentable y lastimosa desgracia de Garachico; hecha, y consagrada a Ntro. Iltmo. y Reve.mo Sor Dn Juan Ruiz Simón, Dignissimo Obispo de estas Yslas de Canaria; Biblioteca de la Universidad de La Laguna: Santa Cruz de Tenerife, Tenerife, Spain, 1709; [Manuscrito] Ms 83.II.10 (F.73-87r).

73. Feuillée, L. Voyage aux Isles Canaries ou Journal des observations Physiques, Mathematiques, Botaniques et Historiques faites par ordre de Sa Majesté, par le R.P.; Louis Feuillée, Religieux, Minime, Mathématicien et Botaniste du Roy: París, France, 1714.

74. Quesada y Chaves, D. Canaria Ilustrada y Puente Americano; Fernández, P.P., Gómez-Pablos, C.C., Padrón, F.R., Eds.; Instituto de Estudios Canarios: La Laguna, Spain, 2007; p. 445.

75. Castañon, J.C.; Quirós, F. La contribución de Bory de Saint-Vicent (1778-1846) al conocimiento geográfico de la Península Ibérica: Redescubrimiento de una obra cartográfica y orográfica olvidad. Ería Rev. Geográfica 2004, 64-65, 177-205.

76. Ponte y Cólogan, A. Volcán del Chinyero. Memoria Histórico-Descriptiva de Esta Erupción Volcánica, Acaecidaen 18 de Noviembre de 1909; Tipolit: Tenerife, Spain, 1911; p. 61.

77. Von Fritsch, K.; Reiss, W. Geologische Beschreibung der Insel Tenerife; Wurster and Co.: Winterthur, Switzerland, $1868 ;$ p. 496.

78. Zurcher, F.; Margollé, E. Volcanes y Terremotos; Biblioteca de maravillas: Barcelona, Spain, 1885; 355p.

79. Silgado, E. Historia de los sismos más notables ocurridos en el Perú (1513-1974). Bol. Ingemmet, Serie C: Geod. Ing Geol. 1978, 3,130 .

80. Tavera, H. Evaluación del Peligro Asociado a los Sismos y Efectos Secundarios en Perú; Instituto Geofísico del Perú, Ministerio de Ambiente: Lima, Peru, 2014; p. 43.

81. Martínez Solares, J.M. Los Efectos en España del Terremoto de Lisboa (1 de noviembre de 1755); Ministerio de Fomento, Instituto Geográfico Nacional: Madrid, Spain, 2001; p. 756.

82. Dirección General de Protección Civil y Emergencias, Costas Españolas. Peligrosidad frente a maremotos 2017. p. 123. Available online: https://www.proteccioncivil.es/documentacion/informes?p_p_id=com_grupoica_publicador_PublicadorPortlet_ INSTANCE_iCEpKxfZtr7Z\&p_p_lifecycle=0\&p_p_state=normal\&p_p_mode=view\&_com_grupoica_publicador_PublicadorPortlet_ INSTANCE_iCEpKxfZtr7Z_javax.portlet.action=buscarResultados (accessed on 26 March 2021).

83. Rodrigues, D. Análise de risco de movimentos de vertente e ordenamento do territorio na Madeira. Aplicaçãocao caso de Machico. Tese de Doutoramento em Geología. Ph.D. Thesis, Universidade da Madeira, Funchal, Portugal, 2005.

84. ISTAC. 2020. Instituto Canario de Estadística. Available online: http://www.gobiernodecanarias.org/istac/estadisticas/ demografia/ (accessed on 11 January 2021). 